\title{
ROBERT HARRY KREBA, 1954-2001
}

PAUL CHYTYK, 2740 Gosworth Road, Victoria BC, V8T 3C3, KARYN SCALISE, 3019 Quinn Drive, Rcgina, SK S4P 2W3 and RON TILLIE, Royal Saskatchewan Museum, Rcgina, SK S4P 3 V7

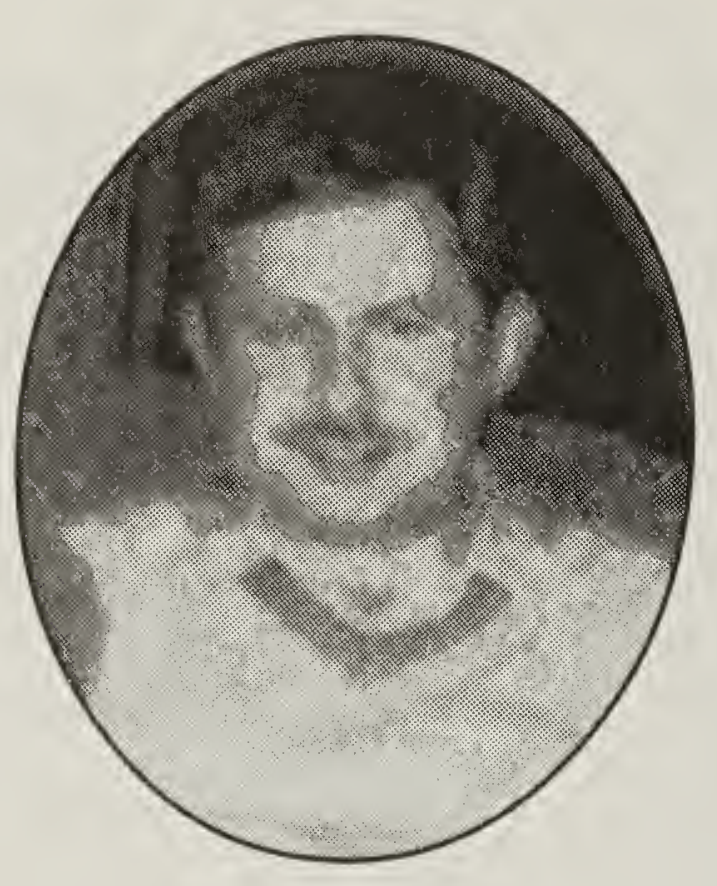

Bob Kreba was born in Yorkton on February 7, 1954. The family moved to Winnipeg the year after Bob's birth and relocated to Regina in 1958. Bob completed elementary school in Regina and attended high school in Weyburn. While in high school, Bob acquired several treasured possessions, which developed into lifelong passions for him - a pair of binoculars, a camera, a telescope, and an aquarium.

As a child, Bob sketched, read and wrote about wildlife and nature. He frequently brought home insects, snakes and injured birds that he cared for and, as someone who wouldn't allow any creature to be hurt or killed, was instrumental in passing on the respect he held for all living things to his sisters. Bob demonstrated his compassion for others as a teenager by befriending several troubled youths and encouraging them to open themselves up to the world and improve themselves. While still a student in Weyburn, he began leading field trips and recruiting prospective birders.

By the early 1970s, Bob was visiting the Saskatchewan Museum of Natural History (now known as the Royal Saskatchewan Museum, RSM) to view the wildlife dioramas and to borrow study skins of particular bird species to learn more about their special features. His familiarity with staff and his eagerness to work at the museum turned into an offer of employment on May $17^{\text {th }} 1976$. Bob continued to work at this museum until his passing. His entire museum career was spent in the Exhibits section, although much of his work was of a curatorial nature. When he started employment, he was trained to print exhibit labels onto cardstock for incorporation into new and existing gallery exhibits. This led to training in the use of the silkscreen process for label development.

Working at the museum allowed better access to all natural history collections and brought him into close association with many other naturalists both at work and in the general public. Bob's desire to share his love of nature was expressed at the museum and through his involvement with the Regina Natural History Society (RNHS). Bob served the RNHS for many years as field trip coordinator, leading many field trips each year. He also gave slide lectures, coordinated the May Day Bird Counts and wrote articles for, and had photographs published in, Blue Jay. Bob served on the RNHS executive for most of the past 20 years, and was Vice-President at the time of his passing.

In 1986, a major museum gallery redevelopment was initiated. Bob worked closely with the curators and exhibits staff to develop the text panels for each gallery. The final gallery to be completed was the Life Sciences Gallery. This is where Bob's input at the RSM is most evident, especially 
in the large, open dioramas. His largest contribution was answering questions by curatorial and exhibits staff and contractors relating to appropriate content, supplying reference material and direction to artists and foreground specialists, and providing the bird and nature sounds in each diorama, through personal field recording. These world class wildlife dioramas would not have been developed to the current level of quality without his input.

Bob had a special ability to open people's eyes to the beauty of nature. It brought him as much pleasure to point things out to visitors as they strolled past open dioramas in the RSM as it did to point things out to people on a field trip.

Bob loved birding and birdwatching. He had searched out every conceivable place for birds near Regina. He co-authored A Bird Finding Guide to the Regina Area in 1985 with his friends Chris Adam, Tom Riffel and Bob Luterbach. However, Bob was just as content to spend hours looking through a scope differentiating the subtle plumage differences between a third winter Herring Gull and a third winter Thayer's Gull. He could explain the differences in the greatest detail as if he was describing the personality differences of two friends. Birds were his greatest delight, not to add to a list, but to understand, appreciate and share with others. $\mathrm{He}$ took meticulous notes of his observations, wrote and published articles, compiled provincial bird records for American Birds, and produced the Field Checklist of Saskatchewan birds.

Bob was a giving man. He had few possessions, but what he had, he shared without pause. His generosity was subtle and unassuming. Few knew that on a modest income he sponsored a foster child in a developing country and donated regularly to conservation organizations and social causes. His arrival to meet a friend was always accompanied with a gift: whether it was a book found in a garage sale, a jar of his famous homemade tomato sauce, or a piece of dreadful tasting candy that even the storekeeper warned him not to buy, there was always a gift for the sheer sake of enjoyment, of sharing and experiencing something together.

Bob was always late: a frustration for the person waiting, but treasured time for the others that he was helping, the friend's cat he was feeding, the volunteer work he was completing, or the field trip he was organizing... all just moments before seeing you.

Bob was kind and sensitive; he wore his feelings and fears openly for others to embrace or push away. He was honest; he could be trusted with the greatest of confidences and he did not hesitate to call a "spade" a "spade". He was truly sympathetic, able to appreciate the pain and sorrow of others, empathizing where others were quick to dismiss. He was argumentative when he wanted to teach or to learn. He always looked frumpled, but that was part of his charm. He had a dry sense of humor whose subtlety was so ingenious that most were unaware of the wit befallen them. Bob had unusual bad luck; it seemed to be drawn to him. If something could go wrong, it usually happened to Bob.

Throughout his life he was extremely generous to his sisters, and family was very important to him. Bob was married briefly to Alison Sapara and they had one child, James, born in 1980. He was a devoted father and had infinite patience in answering James' questions on any topic and in helping James with school projects.

Bob played a leading role in organizing his parents $50^{\text {th }}$ Wedding Anniversary celebration on November 2, 2001, just one week before he passed away in his home on $15^{\text {th }}$ November, leaving his family with many cherished memories of Bob's generosity and kindness. We share in the loss of one of nature's treasures, the loss of our dear friend Bob Kreba. 